\title{
Soil Nitrogen Dynamics following Harvesting and Conversion of Red Alder and Douglas Fir Stands
}

\author{
H. Van Miegroet, ${ }^{*}$ P. S. Homann, and D. W. Cole
}

\begin{abstract}
Drastic reductions in $\mathrm{NO}_{3}{ }^{-}$leaching have been observed after harvesting of mature red alder (Alnus rubra Bong.) stands. Our objective was to examine whether these reduction were linked to changes in soil N dynamics. Adjacent alder and Douglas fir [Pseudotsuga menziessii (Mirbel.) Franco] stands on young glacial soils (Alderwood; a loamyskeletal, mixed, mesic, ortstein Aquic Haplorthod) in western Washington were harvested and replanted with either alder or Douglas fir seedlings; reference plots were established in nearby undisturbed stands. Three years after site conversion, when $\mathrm{NO}_{3}{ }^{-}$leaching declined most drastically in the harvested alder plots, net $\mathrm{N}$ mineralization and net nitrification in the upper soil were determined seasonally by in situ incubation using the buried-bag technique. There were no significant increases in soil $\mathrm{NH}_{4}-\mathrm{N}$ during incubation, indicating that nitrification rates closely followed net $\mathbf{N}$ mineralization in all plots. In the $\mathbf{N}$-poor soils of the harvested and uncut Douglas fir plots, nitrification was consistently $<2 \mu \mathrm{g} \mathrm{N} \mathrm{g}^{-1}$ per $30 \mathrm{~d}$. In the $\mathrm{N}$-rich alder reference plot, nitrification was highest in summer (52 $\mu \mathrm{g} \mathrm{N} \mathrm{g}^{-1}$ per $30 \mathrm{~d}$ ), lowest in winter $\left(4 \mu \mathrm{g} \mathrm{N}^{-1}\right)$, and intermediate in spring $\left(20 \mu \mathrm{g} \mathrm{N} \mathrm{g}^{-1}\right)$. Seasonal fluctuations in nitrification diminished in the harvested alder plots. Nitrification rates were significantly lower than in the uncut alder plot in summer only (5-9 $\mu \mathrm{g} \mathrm{N} \mathrm{g}^{-1}$ per $30 \mathrm{~d}$ ), but this difference was insufficient to account for the lower $\mathrm{NO}_{3}^{-}$leaching rates in the conversion plots. Soils in the harvested plots were drier and experienced greater temperature extremes, but these changes did not correlate well with the variability in $\mathrm{N}$-mineralization rates between uncut and harvested alder plots. Nitrification was positively correlated to soil temperature in the uncut alder plot only. The establishment of red alder seedlings did not appear to have influenced the $\mathrm{N}$ dynamics in either $\mathbf{N}$-poor or $\mathbf{N}$-rich soils.
\end{abstract}

$\mathrm{R}$ ED ALDER is known for its ability to symbiotically fix atmospheric $\mathrm{N}_{2}$. Reported $\mathrm{N}$-fixation rates for this species range from 50 to $200 \mathrm{~kg} \mathrm{ha}^{-1} \mathrm{yr}^{-1}$ (Binkley, 1981; Cole et al., 1978; DeBell and Radwan, 1979; Franklin et al., 1968; Zavitkovski and Newton, 1968). Because of this biological $\mathrm{N}$ input, the prolonged presence of red alder increases total and available soil N (Bormann and DeBell, 1981; Cole et al., 1978; DeBell et al., 1983), and also causes greater N mineralization, higher nitrification rates (Van Miegroet et al., 1989; Van Miegroet et al., 1990b; Binkley et al., 1991) and considerable $\mathrm{NO}_{3}^{-}$leaching through the soil profile (Binkley et al., 1982; Van Miegroet and Cole, 1984).

During an earlier field study in western Washington of the effects of harvesting intensity on nutrient losses, the removal of alder was followed by a significant reduction in soil solution $\mathrm{NO}_{3}^{-}$concentrations (Bigger and Cole, 1983) despite the high soil N levels. Soil

H. Van Miegroet, Environmental Sciences Division, Oak Ridge National Lab., Oak Ridge, TN 37831-6038; P.S. Homann, Dep. of Forest Science, Oregon State Univ., Corvallis, OR 973315705; and D.W. Cole, College of Forest Resources, Univ. of Washington, Seattle, WA 98195 . Publication no. 3877, Environmental Sciences Division, Oak Ridge National Lab. Received 12 Apr. 1991. "Corresponding author.

Published in Soil Sci. Soc. Am. J. 56:1311-1318 (1992). solution monitoring in a subsequent study at a different location also indicated a similar $\mathrm{NO}_{3}^{-}$leaching response to the removal of the red alder cover (Van Miegroet et al., 1990a). After an initial temporary increase, soil solution $\mathrm{NO}_{3}^{-}$levels drastically declined in the second year following harvesting, reaching the lowest levels in the third and fourth year (Fig. 1). The corresponding $\mathrm{NO}_{3}^{-}$levels in a nearby uncut alder stand consistently ranged between 200 and $300 \mu \mathrm{mol} \mathrm{L}^{-1}$ during most of that collection period, and actually increased to $600 \mu \mathrm{mol} \mathrm{L}^{-1}$ in 1988 (Van Miegroet et al., 1990a; Homann et al., 1991, unpublished data). In contrast, soil solution chemistry was not affected by harvesting in nearby Douglas fir sites, and $\mathrm{NO}_{3}^{-}$ concentrations in the soil solutions at these sites remained consistently $<1 \mu \mathrm{mol} \mathrm{L}-1$ (Bigger and Cole, 1983; Van Miegroet et al., 1990a). Such a decline in $\mathrm{NO}_{3}^{-}$leaching following alder removal was unlike the results from other harvesting studies (e.g., Likens et al., 1969; Swank, 1986; Waide et al., 1987) and somewhat unexpected for systems that are typically $\mathbf{N}$ rich (Vitousek et al., 1979). Its cause was not clear, but may include one or more of the following factors: (i) a reduction in litterfall $\mathbf{N}$ input and a decline in readily mineralizable $\mathrm{N}$ substrate in the forest floor, (ii) an increase in $\mathrm{N}$ uptake by the subordinate vegetation, (iii) an increase in microbial $\mathbf{N}$ immobilization or a decrease in $\mathbf{N}$ mineralization in the mineral soil, and (iv) a decline in nitrification potential of the soil.

Nitrogen mineralization and nitrification rates in forest soils strongly depend on the available $\mathrm{N}$ supply in or $\mathbf{N}$ inputs to the soil relative to processes that retain $\mathrm{N}$ in the system (e.g., uptake by plants and microorganisms) (Riha et al., 1986; Rosswall, 1976). Nitrogen mineralization, for example, may be stimulated by $\mathrm{N}$ fertilization (e.g., Heilman, 1974; Johnson et al., 1980; Pang, 1982; Van Miegroet et al., 1990b), or by the elimination of vegetation $\mathrm{N}$ uptake by forest

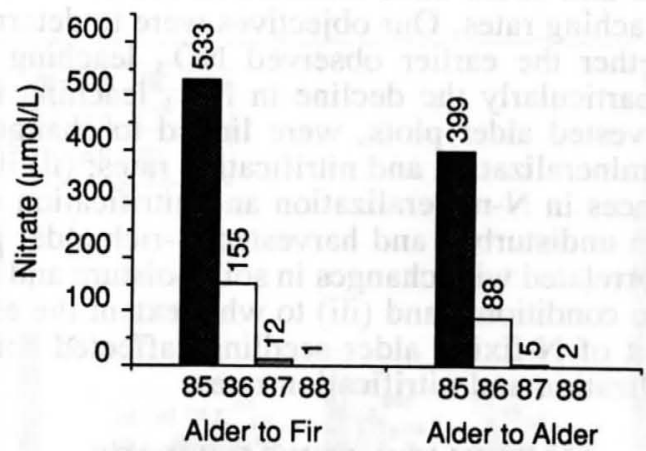

Fig. 1. Volume-weighted average $\mathrm{NO}_{3}^{-}$concentration in $\mathrm{A}$ horizon leachates in the alder conversion plots for the first 4 yr following alder forest removal at the Thompson Research Center (adapted from Van Miegroet et al., 1990a).

Abbreviations: AA, N-rich alder site converted to alder; AF, alder site converted to Douglas fir; FA, N-poor Douglas fir site converted to alder; FF, Douglas fir site converted to Douglas fir; DF, Douglas fir; RA, red alder; ANOVA, analysis of variance. 
harvesting or tree girdling (Johnson and Edwards, 1979; Likens et al., 1969; Vitousek et al., 1979; Waide et al., 1987), although $\mathrm{NO}_{3}^{-}$solution levels have been shown to rapidly decline again with vegetation reestablishment (Bormann et al., 1974; Mann et al., 1988). It is widely assumed that nitrifiers are weak competitors for available $\mathrm{NH}_{4}-\mathrm{H}$, and that $\mathrm{NH}_{4}-\mathrm{N}$ uptake by heterotrophic microorganisms and plants suppresses nitrification in N-poor soils (Riha et al., 1986; Vitousek et al., 1982). Davidson et al. (1990) have recently challenged this assumption and have proposed that the distribution and availability of $\mathrm{NH}_{4}-\mathrm{N}$ among the different organism groups are governed by $\mathrm{NH}_{4}$ diffusion rates, meaning that those organisms closest to $\mathrm{NH}_{4}$ production sites, either nitrifiers or heterotrophs, are most likely to take up that $\mathrm{NH}_{4}-\mathrm{N}$. Regardless of which conceptual model is used (general competition or substrate diffusion), it is clear that any change in the relative $\mathrm{N}$ source- $\mathrm{N}$ sink strengths may alter nitrification and $\mathrm{NO}_{3}^{-}$leaching rates.

Nitrogen transformation processes are further affected by the quality $(\mathrm{C} / \mathrm{N}$ ratio, lignin/ $\mathrm{N}$ ratio) of the organic matter (Berg and Staaf, 1981; Haynes, 1986; Melillo et al., 1982) and environmental site conditions such as temperature and soil moisture content (e.g., Ellis, 1974; Nadelhofer et al., 1983; Pastor and Post, 1986; Waide et al., 1987; Powers, 1990). Changes in these characteristics may also have occurred following the removal of the forest cover.

Our study focused on $\mathrm{N}$ mineralization and nitrification in the mineral soil because an earlier forest floor manipulation experiment in an uncut alder stand had suggested that the belowground $\mathrm{N}$ cycling patterns may play an equally if not greater role than the litterfall-leaf decomposition pathway in regulating $\mathrm{NO}_{3}^{-}$ leaching patterns (Van Miegroet et al., 1990b). Also, Zavitkovski and Newton (1968) had found that more than one-half of the $\mathrm{N}$ accretion rates in 2- to 14-yrold red alder stands could not be accounted for by aboveground $\mathrm{N}$ accumulation and litterfall, but probably originated from root exudates (and root turnover) and $\mathrm{N}_{2}$ fixation by free-living bacteria. Accordingly, changes in root dynamics caused by tree removal could have directly impacted the $\mathrm{N}$ supply to soil microorganisms and could have altered soil nitrification and $\mathrm{NO}_{3}^{-}$leaching rates. Our objectives were to determine (i) whether the earlier observed $\mathrm{NO}_{3}^{-}$leaching patterns, particularly the decline in $\mathrm{NO}_{3}^{-}$leaching from the harvested alder plots, were linked to changes in soil N-mineralization and nitrification rates; (ii) if any differences in $\mathrm{N}$-mineralization and nitrification rates between undisturbed and harvested $\mathrm{N}$-rich alder plots were correlated with changes in soil moisture and temperature conditions; and (iii) to what extent the establishment of $\mathrm{N}$-fixing alder seedlings affected soil $\mathrm{N}$ mineralization and nitrification rates.

\section{MATERIALS AND METHODS}

\section{Site Description}

The research was conducted at the University of Washington's Thompson Research Center in the Cedar River watershed. The site is on the western foothills of the Washington Cascade Mountains, $56 \mathrm{~km}$ southeast from Seattle. The climate is maritime, with cool, dry summers and wet moderate winters. Mean annual temperature is $9.8^{\circ} \mathrm{C}$ and mean annual precipitation is $\approx 1300 \mathrm{~mm}$, most of which falls as rain between October and March. Two forest types are found adjacently at the site: Douglas fir plantations, established in the early 1930 s following clear-cutting of the old-growth forest, and red alder seeded in naturally a few years later in the areas that were not replanted with conifers. The Douglas fir stand contains 1100 stems ha-1, corresponding to a basal area of $50 \mathrm{~m}^{2} \mathrm{ha}^{-1}$. It is classified as a low Site III (King, 1966) with a site index of 106 (32 m) for Douglas fir at age 50. The density in the red alder stand is 800 stems ha-1 with a basal area of $36 \mathrm{~m}^{2} \mathrm{ha}^{-1}$. The site is classified as a Site Class III with a site index of 111 $(34 \mathrm{~m})$ for Douglas fir at $50 \mathrm{yr}$. The Alderwood soil underlying both forest types, previously classified as a Dystric Entic Durochrept, is currently classified as an Aquic Haplorthod (Soil Conservation Service, 1986). It is of glacial origin and developed from ablation till over a compacted basal till layer. It has a gravelly sandy loam texture (Cole and Gessel, 1968).

\section{Forest Conversion}

A detailed description of the forest conversion experiment can be found in Van Miegroet et al. (1990a). In the fall of 1984, all overstory vegetation was removed from a 1-ha area in each of the adjacent Douglas fir and red alder forests. The trees were carefully lifted from the site with a cable system to prevent the forest floor and soil disturbances associated with conventional logging operations. In February 1985 , one-half of each clear cut area was replanted with red alder and one-half with Douglas fir seedlings, yielding four 0.5 -ha conversion units: $\mathrm{N}$-rich alder site converted to alder (AA), alder to Douglas fir (AF), N-poor Douglas fir site converted to alder (FA), and Douglas fir to Douglas fir (FF). Plots $(20$ by $20 \mathrm{~m})$ in nearby unharvested Douglas fir (DF) and red adler (RA) stands were used to serve as undisturbed controls (Fig. 2). Chemical analyses prior to harvesting showed that the soils in the conversion plots were similar to those in the corresponding reference plots (Table 1; Van Miegroet and Cole, 1984, 1989).

\section{Field and Laboratory Measurements}

In the third year after forest conversion, net soil $\mathrm{N}$-mineralization and nitrification rates in the field were determined in the reference plots and the four conversion plots through in situ incubation by using the buried-bag technique (Eno, 1960). Measurements were made in July and October 1987 and February and May 1988 to broadly characterize

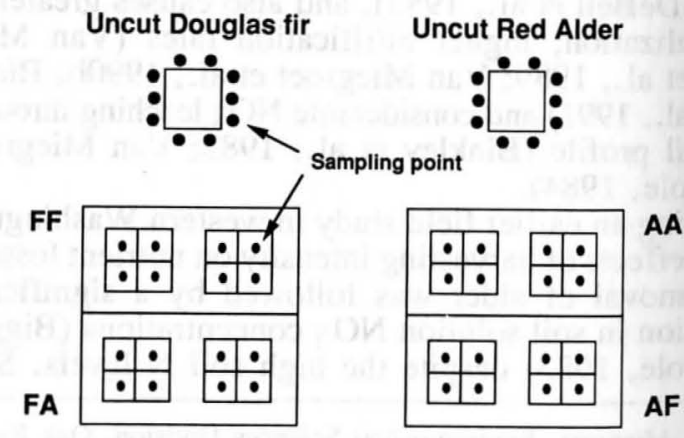

\section{Douglas fir Clearcut Red Alder Clearcut}

Fig. 2. Plot layout and location of soil sampling points in the red alder and Douglas fir reference and conversion plots at the Thompson Research Center. 
summer, fall, winter, and spring conditions, respectively. Incubations were also conducted in the reference plots in May 1987. Two 5.75-cm-diam. cores were taken in the mineral soil to a depth of $10 \mathrm{~cm}$ at the centers of eight 15 by $15 \mathrm{~m}$ subplots in each of the four conversion units (eight replicates) and at ten sampling points located at regular distances around the periphery of each reference plot (10 replicates), respectively (Fig. 2). Of each pair of soil cores, one was taken back to the laboratory within a few hours and refrigerated until extraction (usually within $2 \mathrm{~d}$ of sampling). These soil samples represented initial, preincubation conditions. The second core was sealed in a plastic bag, slipped back into the hole, covered with forest floor material or variable thickness depending on the plot and sampling point, and left in the field for $\approx 1 \mathrm{mo}$. Upon retrieval from the field, soil samples were also kept refrigerated until extraction. They constituted postincubation conditions. At the beginning and the end of each incubation period, soil temperatures at the $10-\mathrm{cm}$ depth were recorded at each sampling point to the nearest $0.5^{\circ} \mathrm{C}$ using a dial thermometer.

Each soil sample was mixed thoroughly prior to extraction. Inorganic $\mathrm{N}$ was extracted by placing 5 to $10 \mathrm{~g}$ of field-moist soil in a centrifuge tube, shaking the soil for $\approx 2 \mathrm{~h}$ with $20 \mathrm{~mL}$ of $2 M \mathrm{KCl}$, and centrifuging the sample. The supernatant was analyzed for $\mathrm{NH}_{4}-\mathrm{N}$ and $\mathrm{NO}_{3}-\mathrm{N}$ using a Technicon Autoanalyzer. Soil moisture content was determined on subsamples dried for $24 \mathrm{~h}$ at $105^{\circ} \mathrm{C}$ and cooled in a desiccator. All concentrations were converted to an oven-dry-weight basis. Net nitrification during a 30-d period was calculated as the difference between final and initial $\mathrm{NO}_{3}-\mathrm{N}$ in the paired samples, and net $\mathrm{N}$ mineralization as the difference between initial and final inorganic $\mathrm{N}\left(\mathrm{NH}_{4}-\mathrm{N}+\mathrm{NO}_{3}-\mathrm{N}\right)$ concentrations. All $\mathrm{NH}_{4}$ and $\mathrm{NO}_{3}$ concentrations and $\mathrm{N}$-mineralization and nitrification rates are expressed in terms of micrograms of $\mathrm{N}$ per gram of dry soil.

\section{Statistical Analysis}

The lack of plot replication in the original site manipulation design allowed us to test differences between plots

Table 1. Selected properties of the soils (standard error of the mean in parentheses) in the Douglas fir and red alder reference sites and in the conversion sites prior to harvesting (expanded from Van Miegroet and Cole, 1984, 1989; Van Miegroet et al., 1990b).

\begin{tabular}{|c|c|c|c|c|c|}
\hline $\begin{array}{c}\text { Horizon } \\
\text { and } \\
\text { depth }\end{array}$ & $\begin{array}{c}\text { Bulk } \\
\text { Density }\end{array}$ & $\underset{\mathrm{H}_{2} \mathrm{O}}{\mathrm{pH} \text { in }}$ & $\begin{array}{c}\text { Total } \\
\text { C }\end{array}$ & $\begin{array}{c}\text { Total } \\
\mathbf{N}\end{array}$ & $\mathrm{C} / \mathrm{N}$ \\
\hline $\mathrm{cm}$ & $\mathrm{Mg} \mathrm{m}^{-3}$ & & $\mathrm{~g} \mathrm{~kg}^{-1}$ & $\mathrm{~g} \mathrm{~kg}^{-1}$ & \\
\hline & \multicolumn{5}{|c|}{$\underline{\text { Red alder reference }}$} \\
\hline \multirow[t]{2}{*}{$\begin{array}{l}\text { A }(0-7) \\
\text { E }(7-15) \\
\text { B }(15-30) \\
\text { B }(30-45)\end{array}$} & $\begin{array}{l}0.96 \\
\\
1.89 \\
1.30\end{array}$ & $\begin{array}{l}4.5(0.2) \\
4.9(0.1) \\
5.2(0.1) \\
5.5(0.1)\end{array}$ & $\begin{array}{rr}118 & (19) \\
62 & (7) \\
57 & (5) \\
41 & (4)\end{array}$ & & $\begin{array}{ll}17 & (1) \\
16 & (2) \\
17 & (1) \\
16 & (2)\end{array}$ \\
\hline & \multicolumn{5}{|c|}{ Douglas fir reference } \\
\hline \multirow[t]{2}{*}{$\begin{array}{l}\text { A }(0-7) \\
\text { E }(7-15) \\
\text { B }(15-30) \\
\text { B }(30-45)\end{array}$} & $\begin{array}{l}1.03 \\
\\
1.13 \\
1.34\end{array}$ & $\begin{array}{l}5.0(0.1) \\
5.6(0.1) \\
5.5(0.1) \\
5.5(0.1)\end{array}$ & $\begin{array}{ll}80 & (7) \\
46 & (6) \\
33 & (5) \\
28 & (6)\end{array}$ & $\begin{array}{l}3.1(0.4) \\
2.0(0.3) \\
1.7(0.2) \\
1.5(0.2)\end{array}$ & $\begin{array}{ll}26 & (1) \\
24 & (2) \\
19 & (2) \\
19 & (2)\end{array}$ \\
\hline & \multicolumn{5}{|c|}{$\underline{\text { Red alder conversion }}$} \\
\hline \multirow[t]{2}{*}{$\begin{array}{l}A+E(0-15) \\
B(15-30) \\
B(30-45)\end{array}$} & $\begin{array}{l}0.87(0.06) \\
0.84(0.06) \\
0.99(0.09)\end{array}$ & $\begin{array}{l}4.5(0.1) \\
4.8(0.1) \\
4.9(0.1)\end{array}$ & $\begin{array}{ll}95 & (7) \\
59 & (4) \\
58 & (6)\end{array}$ & $\begin{array}{l}4.8(0.4) \\
3.2(0.2) \\
3.1(0.3)\end{array}$ & $\begin{array}{ll}20 & (7) \\
19 & (1) \\
19 & (1)\end{array}$ \\
\hline & \multicolumn{5}{|c|}{ Douglas fir conversion } \\
\hline $\begin{array}{l}A+E(0-15) \\
B(15-30) \\
B(30-45)\end{array}$ & $\begin{array}{l}0.96(0.04) \\
1.03(0.04) \\
1.08(0.07)\end{array}$ & $\begin{array}{l}5.3(0.1) \\
5.3(0.1) \\
5.3(0.1)\end{array}$ & $\begin{array}{ll}43 & (3) \\
29 & (3) \\
26 & (2)\end{array}$ & $\begin{array}{l}1.6(0.1) \\
1.2(0.1) \\
1.2(0.1)\end{array}$ & $\begin{array}{l}28(12) \\
24(8) \\
21(10)\end{array}$ \\
\hline
\end{tabular}

only and not between harvesting-replanting treatments per se. The AF and AA plots on the one hand, and the FF and FA plots on the other, however, had shown a consistent patterns in terms of $\mathrm{NO}_{\overline{3}}$ solution chemistry (Van Miegroet et al., 1990a), and we wanted to test whether subsequent measurements of soil $\mathrm{N}$ dynamics were equally consistent. Differences between plots and sampling dates of soil $\mathrm{NH}_{4}$ and $\mathrm{NO}_{3}$ concentrations, net $\mathrm{N}$-mineralization rates, and nitrification rates were tested through one-way ANOVAs, followed by a Duncan's multiple-range test $(P<0.05)$ where appropriate. Plot means that were not statistically different from one another are indicated by the same letter in all the figures. Each date-plot combination was considered a separate level in the ANOVA. This approach was taken (i) to allow May 1987 reference plot data to be analyzed concomitantly with data from the other seasons where both reference and conversion plot data existed, and (ii) because preliminary analysis with two-way ANOVAs indicated significant date $\times$ plot interaction, requiring a different statistical approach to separate individual date-plot means. In addition, $t$-tests were used to determine whether individual plot means were significantly different from zero (SAS Institute, 1985; Zar, 1974), i.e., whether the measured concentrations or rates were biologically meaningful. Simple linear regression and stepwise multiple regression were used to examine the relationship of $\mathrm{N}$-mineralization and nitrification rates to selected soil properties in the $\mathrm{N}$ rich alder (RA, AA, and AF) plots. Only those variables were included in the regression model that met the $\mathbf{0 . 1 5}$ significance level for entry (SAS Institute, 1985).

\section{RESULTS AND DISCUSSION}

\section{Nitrogen Transformations in Nitrogen-Poor Douglas Fir Soils}

Initial $\mathrm{NH}_{4}$ concentrations in DF, FF, and FA soils were $<5 \mu \mathrm{g} \mathrm{N} \mathrm{g}^{-1}$ and did not differ between plots or sampling dates (Fig. 3); initial $\mathrm{NO}_{3}$ levels were consistently $<1.1 \mu \mathrm{g} \mathrm{N} \mathrm{g^{-1 }}$ in all plots. Net nitrification rates were generally low and individual plot means could not be shown to be different from zero, except for the FF plot in May 1988 (Fig. 4). Only small changes in soil $\mathrm{NH}_{4}-\mathrm{N}$ concentrations were measured during incubation, and plot means again did not differ statistically from zero except for the FA plot in May 1988 (Fig. 5). The results indicated that virtually no net mineralization occurred in any of the N-

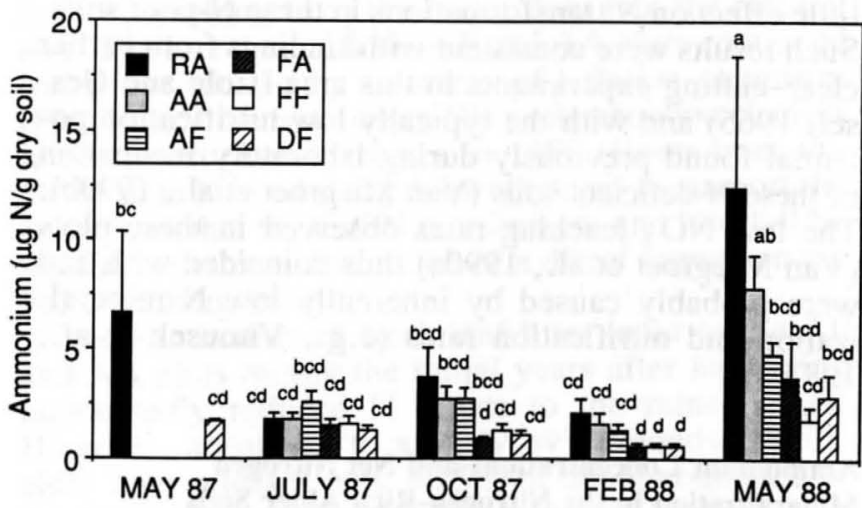

Fig. 3. Average $\mathrm{NH}_{4}$ concentration of the upper soil in the red alder and Douglas fir reference and conversion plots. Error bars represent standard error of the mean; plot means with the same letter are not significantly different from each other $(P=0.05)$. 


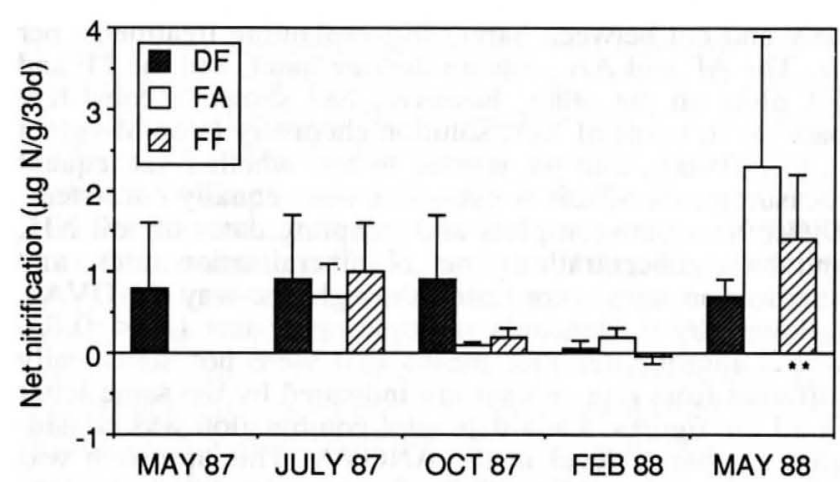

Fig. 4. Average net nitrification during in situ incubation of $\mathrm{N}$-poor soils in the Douglas fir reference and conversion plots. Error bars represent standard error of the mean; ** indicates plot average significantly different from zero $(P$ $=0.01$ ).

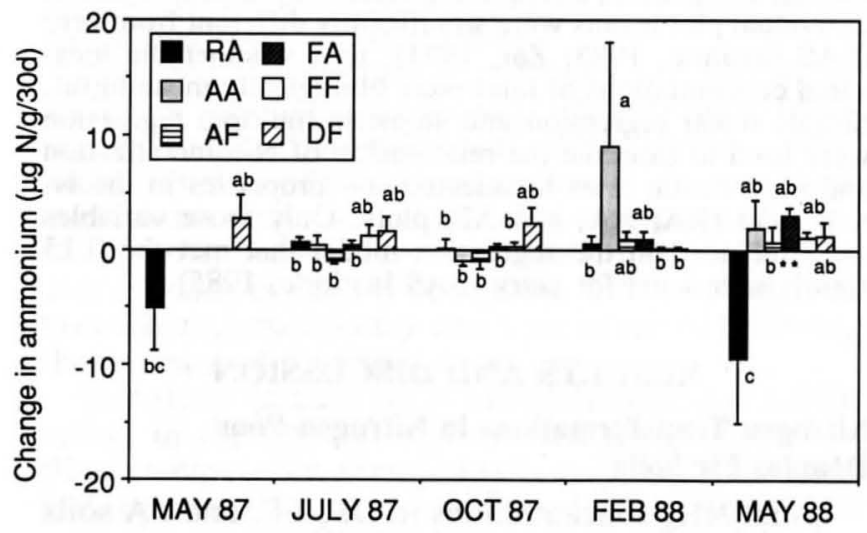

Fig. 5. Change in $\mathrm{NH}_{4}$ concentration during in situ incubation of soils in the red alder and Douglas fir reference and conversion plots. Error bars represent standard error of the mean; plot means with the same letter are not significantly different from each other $(P=0.05)$; ${ }^{* *}$ indicates plot average significantly different from zero $(P=0.01)$.

poor Douglas fir plots. These consistently low rates and the lack of detectable differences in net nitrification rates between the undisturbed (DF) and the harvested (FF and FA) plots suggested that site manipulation (vegetation removal and replanting) had little effect on $\mathrm{N}$ transformations in these $\mathrm{N}$-poor soils. Such results were consistent with findings from earlier clear-cutting experiments in this area (Cole and Gessel, 1965) and with the typically low nitrification potential found previously during laboratory incubation of these N-deficient soils (Van Miegroet et al., 1990b). The low $\mathrm{NO}_{3}$ leaching rates observed in these plots (Van Miegroet et al., 1990a) thus coincided with and were probably caused by inherently low $\mathrm{N}$ mineralization and nitrification rates (e.g., Vitousek et al., 1982).

\section{Ammonium Concentrations and Net Nitrogen} Mineralization in the Nitrogen-Rich Alder Soils

Mean soil $\mathrm{NH}_{4}-\mathrm{N}$ concentrations in the soil were $<5 \mu \mathrm{g} \mathrm{g}^{-1}$ with no significant differences between sampling dates and between the $\mathrm{N}$-rich reference (RA) and the conversion (AF and $\mathrm{AA}$ ) plots, except for May

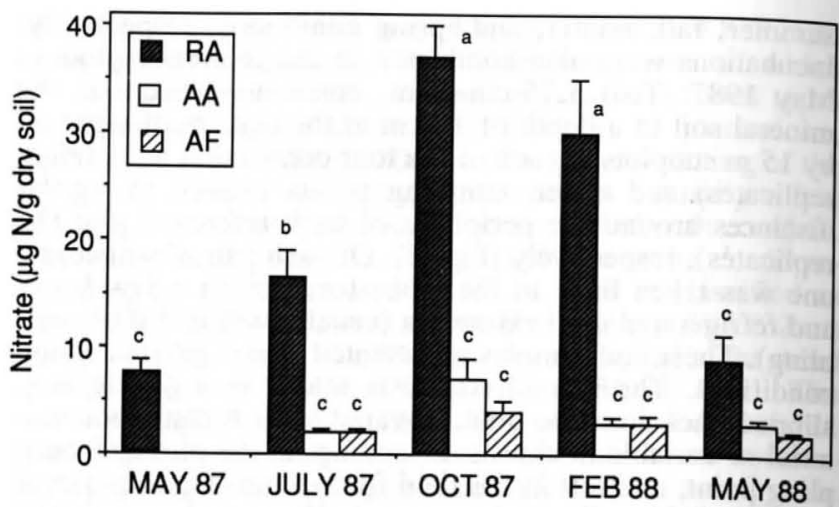

Fig. 6. Mean preincubation nitrate concentration in the $\mathbf{N}$ rich soils in the red alder reference and conversion plots. Error bars represent standard error of the mean; plot means with the same letter are not significantly different from each other $(P=0.05)$.

1988 (Fig. 3). Plot means were also similar to those in the N-poor (DF, FA, and FF) plots, except in the case of the RA plot in May $1987\left(7 \mu \mathrm{g} \mathrm{g}^{-1}\right)$ and May $1988\left(12 \mu \mathrm{g} \mathrm{g}^{-1}\right)$ and the AA plot in May 1988 (8 $\left.\mu \mathrm{g} \mathrm{g}^{-1}\right)$. The highest $\mathrm{NH}_{4}-\mathrm{N}$ levels in the individual field samples were measured in the alder reference plot: 16, 40, and $61 \mu \mathrm{g} \mathrm{g}^{-1}$ in October 1987 and May 1987 and 1988, respectively. Because of the high coefficients of variation, particularly in the alder reference plot, the mean soil $\mathrm{NH}_{4}-\mathrm{N}$ concentration was significantly higher in the RA plot only in May 1988.

Changes in soil $\mathrm{NH}_{4}-\mathrm{N}$ concentrations during incubation remained low and were not statistically different from zero. The relative stability of soil $\mathrm{NH}_{4}$ levels is not an unusual occurrence in forest soils, even during incubation (e.g., Van Miegroet et al., $1990 \mathrm{~b})$. This pattern is consistent with the conceptual model of Riha et al. (1986), which states that the nitrifier activity is largely dependent on and controlled by the flow of $\mathrm{NH}_{4}$ during ammonification of organic $\mathrm{N}$, or with the diffusion model of Davidson et al. (1990) if microbial $\mathrm{N}$ immobilization is considered nonselective and proportional to production rates. Thus, with nitrification rates closely following net ammonification rates, soil $\mathrm{NH}_{4}$ levels will fluctuate within a relatively narrow range, even in $\mathrm{N}$-enriched soils. Average $\mathrm{N}$ mineralization $\left(\mathrm{NH}_{4}-\mathrm{N}+\mathrm{NO}_{3}-\mathrm{N}\right)$ ranged from 4 to $52 \mu \mathrm{g} \mathrm{g}^{-1}$ per $30 \mathrm{~d}$ in the alder reference plot, and from 0 to $25 \mu \mathrm{g} \mathrm{g}^{-1}$ per $30 \mathrm{~d}$ in the alder conversion plots. Net nitrification rates averaged $87 \%$ of net $\mathrm{N}$ mineralization in these $\mathrm{N}$-rich soils and ranged from 27 to $100 \%$. Hence, when net $\mathrm{N}$-mineralization rates $\left(\mathrm{NH}_{4}+\mathrm{NO}_{3}\right)$ were high, they were mostly dominated by fluctuations in net nitrification rates; when $\mathrm{N}$-mineralization rates were low, net nitrification rates were concurrently low. Consequently, only soil nitrification rates will be further discussed.

\section{Differences in Soil Nitrate Dynamics between the Nitrogen-Rich Plots}

Soil $\mathrm{NO}_{3}$ concentrations varied seasonally in the alder reference forest (Fig. 6). They were highest in the fall and winter (37 and $30 \mu \mathrm{g} \mathrm{N} \mathrm{g}^{-1}$ dry soil, respectively), and generally lowest in May 1987 and 
1988 (8-9 $\left.\mu \mathrm{g} \mathrm{g}^{-1}\right)$. There was no difference between the patterns in the AA and $\mathrm{AF}$ plots: initial soil $\mathrm{NO}_{3}-$ $\mathrm{N}$ levels were consistently low (2-7 $\left.\mu \mathrm{g} \mathrm{g}^{-1}\right)$ and were significantly lower than those in the alder reference plot, except in May 1988. Preincubation inorganic N concentrations in these soils did not differ significantly between sampling dates.

Soil nitrification rates in the undisturbed alder (RA) stand fluctuated significantly with time (Fig. 7). The highest net $\mathrm{NO}_{3}-\mathrm{N}$ production was measured in July 1987 (52 $\mu \mathrm{g} \mathrm{g}^{-1}$ per $30 \mathrm{~d}$ ) and the lowest in February 1988 (4 $\mathrm{g} \mathrm{g} \mathrm{g}^{-1}$ per $\left.30 \mathrm{~d}\right)$. Spring nitrification rates were intermediate but consistent from one year to another $\left(\approx 20 \mu \mathrm{g} \mathrm{g}^{-1}\right.$ per $\left.30 \mathrm{~d}\right)$. Nitrification patterns did not differ between the AF and AA plots throughout the study. Net nitrification rates in these plots were significantly lower than in the RA reference plot in July 1987 only, but were not significantly different from the reference plot values at the other sampling dates. Furthermore, the apparent decline in net nitrification observed from July 1987 to February 1988 in the RA plot was significantly attenuated in the conversion plots. Towards spring 1988 , net nitrification rates in the conversion plots increased significantly concurrently with those in the reference plot.

The seasonal fluctuations in soil $\mathrm{NO}_{3}$ concentrations and nitrification rates in the alder reference plot illustrate the dynamic nature of the soil $\mathrm{N}$ balance in an undisturbed alder stand. The temporal trends in soil $\mathrm{NO}_{3}-\mathrm{N}$ concentration did not parallel $\mathrm{NO}_{3}$ production rates (Fig. 6 and 7), suggesting that other processes (including leaching and uptake) were also important in regulating soil $\mathrm{NO}_{3}-\mathrm{N}$ levels. The high $\mathrm{NO}_{3}$ production rates during the summer (July) of 1987 combined with the low water flux during that period $(<3$ $\mathrm{cm}$ of precipitation from July through October 1987; J.E. Compton, 1990, personal communication), probably yielded the high soil $\mathrm{NO}_{3}$ levels in October. Lack of $\mathrm{N}$ uptake by the vegetation during the winter months and leaching into the mineral soil of $\mathrm{N}$ from recently deposited and easily decomposable leaf litter may have accounted for elevated soil $\mathrm{NO}_{3}$ levels in February. On the other hand, the increase in root activity and $\mathrm{N}$ uptake by the vegetation in spring probably immobi-

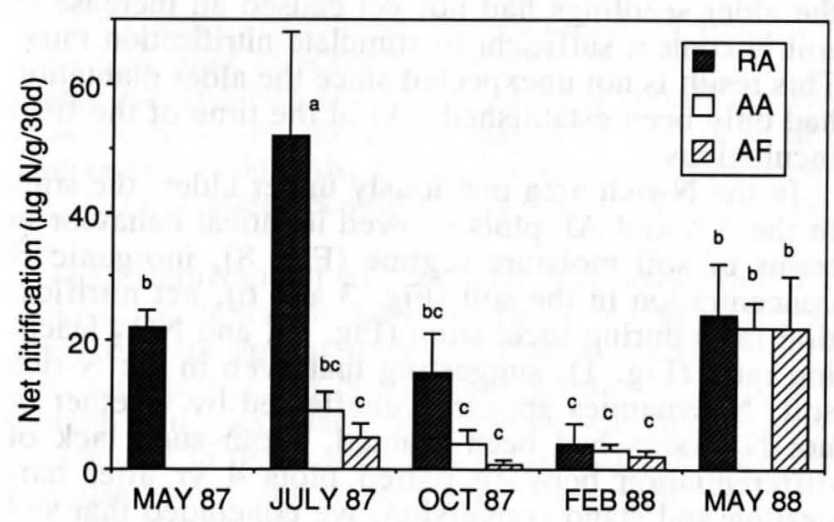

Fig. 7. Average net nitrification during in situ incubation of $\mathrm{N}$-rich soils in the red alder reference and conversion plots. Error bars represent standard error of the mean; plot means with the same letter are not significantly different from each other $(P=0.05)$. lized a large portion of the inorganic $\mathrm{N}$ released during $\mathrm{N}$ mineralization and nitrification, resulting in the rather low soil $\mathrm{NO}_{3}$ values observed in spring.

The removal of the $\mathrm{N}$-fixing alder cover was associated with a significant change in the $\mathrm{N}$ cycling patterns, which was apparently also reflected in the soil $\mathrm{N}$ dynamics. The AA and AF plots consistently showed identical responses. Compared with the uncut RA plot, temporal fluctuations in both nitrification rates and soil $\mathrm{NO}_{3}-\mathrm{N}$ levels were substantially reduced in the AA and AF plots. The lower $\mathrm{NO}_{3}-\mathrm{N}$ levels in the upper soil matched the generally lower $\mathrm{NO}_{3}$ leaching rates observed in these plots (Fig. 1; Van Miegroet et al., 1990a). However, even though measured net nitrification rates in the AA and AF plots were generally low in three out of four sampling periods, they were significantly lower than RA plot values only during the summer (Fig. 7). Thus, the drastic and prolonged reductions in soil solution $\mathrm{NO}_{3}^{-}$concentrations could not be explained by these temporary changes in net $\mathrm{N}$ mineralization and nitrification rates alone.

Other processes potentially affecting the $\mathrm{NO}_{3}$ balance include plant uptake, leaching input from the forest floor, and microbial immobilization. As to the role of vegetation, $\mathrm{N}$ requirements and uptake by the 3-yr old seedlings, particularly the Douglas fir, were probably small compared with $\mathrm{N}$ requirements of a mature alder forest (e.g., Turner et al., 1976; Van Cleve et al., 1971), as indicated by the subsequent aboveground biomass measurements (Cole et al., 1990). The same analysis estimated understory vegetation biomass values in the $\mathrm{AA}$ and $\mathrm{AF}$ plots that were smaller than or similar to values reported for the nearby mature alder forest (Cole and Rapp, 1981; Johnson and Lindberg, 1992), suggesting that the observed differences in $\mathrm{NO}_{3}$ dynamics were also not caused by differences in understory $\mathrm{N}$-uptake rates. Nitrogen requirement and uptake by the young alder seedlings was probably higher than for the Douglas fir seedlings (Cole et al., 1990), especially $4 \mathrm{yr}$ after planting when the alders were fully expanding their leaf canopy. However, such an increase in foliage-related $\mathrm{N}$ uptake should likewise have resulted in a coincident increase in $\mathrm{N}$ return via litterfall, an increase in $\mathrm{N}$ release via decomposition of the fresh material, and an increase in $\mathrm{NO}_{3}^{-}$leaching from the forest floor into the mineral soil. The fact that both the AF and AA plots continued to behave identically in terms of solution chemistry (Fig. 1), and the lack of any $\mathrm{NO}_{3}^{-}$concentration changes in the forest floor leachates in 1988 (Homann et al., 1991, unpublished data) does not seem to support the contention that the leaf $\mathrm{N}$ requirement and litterfall by seedlings pathway had much of a direct impact on the $\mathrm{NO}_{3}^{-}$leaching flux.

The elimination of fresh leaf litter input to the AF and AA plots during the initial years after harvesting undoubtedly reduced $\mathrm{N}$ inputs to the mineral soil. However, according to a study by Edmonds (1980), alder litter releases only $\approx 25 \%$ of the $N$ contained in the fresh litter within the first year and continues to release $\mathbf{N}$ past the second year of decomposition. Thus, even though $\mathrm{N}$ release from the forest floor into the mineral soil may have been reduced with the aging of 
the litter material and the temporary reduction in fresh litter input, this pattern is unable to explain the more than 10 -fold reduction in $\mathrm{NO}_{3}$ solution concentrations between 1986 and 1987 (Fig. 1; Homann et al., 1991, unpublished data). Also, as discussed above, the leaching pattern should have been reversed with an increase in fresh leaf litter input in the AA plot. The consistent behavior of the AA and AF plots and the persistently low $\mathrm{NO}_{3}^{-}$leaching rates, however, suggest prolonged drastic changes in $\mathbf{N}$ dynamics that have remained as of yet unaffected by the subsequent cover.

Our data can only suggest that the removal of alder forest cover caused changes in the relative rate of microbial $\mathrm{N}$-mineralization and $\mathrm{N}$-immobilization processes in the soil and forest floor, but it is not clear what mechanism(s) caused this change. Nitrogen immobilization in the forest floor or mineral soil was not assessed in this study and may actually have played a critical role in regulating $\mathrm{NO}_{3}^{-}$solution fluxes. Also, removing the alder from the site would also have eliminated symbiotic $\mathrm{N}_{2}$ fixation, and the $\mathrm{N}$ enrichment of the rhizosphere via root exudation and fine-root turnover. Our study did not assess the role of belowground organic-matter turnover on $\mathrm{N}$ supply and nitrification rates.

\section{Relationship between Net Nitrification Rates and Soil Properties in the Nitrogen-Rich Soils}

Alder forest removal appeared to have altered the temperature and moisture regime of the soils. Soils in the alder conversion plots ( $\mathrm{AA}$ and $\mathrm{AF}$ ) were generally drier and characterized by greater temperature extremes than the soils in the uncut RA plot (Fig. 8). They were generally warmer in spring and summer and colder in fall and winter, with differences most pronounced between the RA and AF plots. The soil moisture regime further showed less seasonal variation in the AA and AF plots than in the RA plot. The lower soil moisture content in the AA and AF plots may have been the reflection of greater evaporative losses from the exposed soils associated with the higher soil temperatures. There was no significant correlation between net nitrification and soil moisture content across all samples $(n=114)$. Soil moisture contents recorded in this study were rather high, especially in the reference plot, and low soil water availability was probably not a factor limiting $\mathrm{N}$-mineralization rates. On the contrary, high water contents in the RA soils in spring may actually have depressed nitrification rates. Seasonal net nitrification rates in the RA plot (Fig. 5) indeed followed the inverse pattern of the soil moisture content (Fig. 8). On the other hand, the lower soil moisture content in the AA and AF plots did not result in higher net nitrification rates.

Differences in soil temperature explained $<10 \%$ of the variation in net nitrification, but this relationship could be improved to $20 \%$ by introducing an indicator variable in the model to distinguish between reference and conversion plots. In the alder reference plot, soil temperature at the end of the incubation was the single most important factor, explaining $26 \%(P=0.002)$ of the variability in net nitrification $(n=50)$. Initial inorganic $\mathrm{N}$ levels $\left(\mathrm{NH}_{4}\right.$ and/or $\left.\mathrm{NO}_{3}\right)$ in the soil did

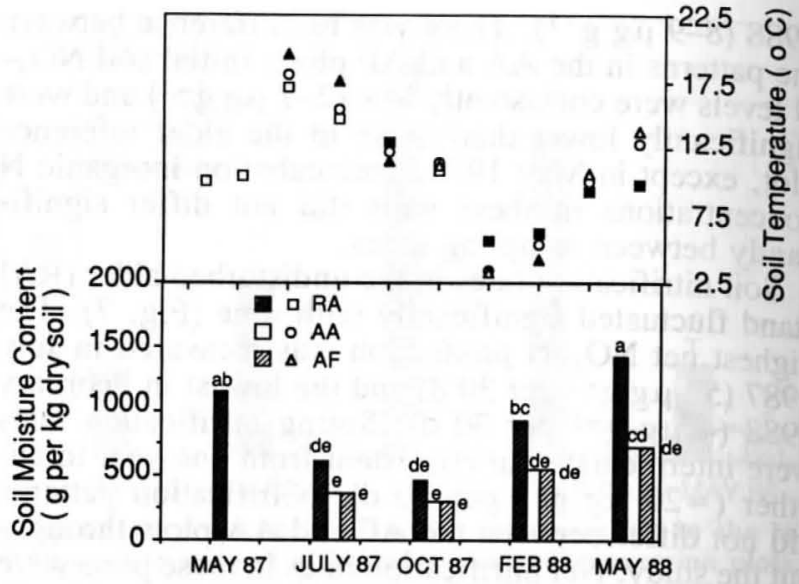

Fig. 8. Average soil moisture content and soil temperatures at $5-\mathrm{cm}$ depth during incubation in the red alder reference and conversion plots. Mean moisture contents with the same letter are not significantly different from each other $(P=$ 0.05); solid symbols indicate mean temperatures that are either significantly lower or higher than the other plot means $(P=0.05)$ for each measurement date.

not contribute to explaining the variation in nitrification rates, either in the alder reference plot or across all three N-rich plots, suggesting that there was neither a positive not a negative feedback between initial inorganic- $\mathrm{N}$ levels and net $\mathrm{N}$-mineralization and nitrification rates in those plots.

\section{Effect of Red Alder Seedlings on Soil Nitrogen Dynamics}

The effect of the establishment of red alder on soil $\mathrm{N}$ dynamics was evaluated by comparing soil $\mathrm{NO}_{\overline{3}}$ concentrations and nitrification rates between pairs of plots replanted with either alder or Douglas fir seedlings in sites at two ends of the $\mathrm{N}$-availability spectrum: i.e., the FA and the FF plots on the $\mathrm{N}$-poor soil and the AA and AF plots on the N-rich soil (Fig. 2). Soil $\mathbf{N}$ dynamics were not different between the paired plots within each harvesting unit ( $\mathrm{N}$ status). In the area previously under Douglas fir, net nitrification rates were consistently at or near zero in both the FA and FF plots, suggesting that $\mathrm{N}_{2}$ fixation associated with the alder seedlings had not yet caused an increase in soil $\mathrm{N}$ content sufficient to stimulate nitrification rates. This result is not unexpected since the alder plantation had only been established $3 \mathrm{yr}$ at the time of the field incubations.

In the $\mathrm{N}$-rich area previously under alder, the soils in the AA and AF plots showed identical behavior in terms of soil moisture regime (Fig. 8), inorganic $\mathrm{N}$ concentration in the soil (Fig. 3 and 6), net nitrification rates during incubation (Fig. 7), and $\mathrm{NO}_{3}^{-}$leaching rates (Fig. 1), suggesting that even in the N-rich soil, $\mathbf{N}$ dynamics appeared unaffected by whether or not $\mathrm{N}_{2}$ fixers had been planted. From such lack of differentiation between paired plots $4 \mathrm{yr}$ after harvesting and stand conversion, we concluded that soil processes at this stage were still largely controlled by site characteristics associated with the prior forest cover, or by changes in these properties caused by harvesting, rather than by forest conversion. 


\section{CONCLUSIONS}

This study showed that there was not a consistent relationship between $\mathrm{NO}_{3}^{-}$leaching patterns and net $\mathrm{N}$-mineralization and nitrification rates in the mineral soil. The N-poor soils of three plots, currently or previously under Douglas fir cover, were characterized by inherently low $\mathrm{N}$-mineralization and nitrification rates that implied limited $\mathrm{N}$ availability and could account for the low $\mathrm{NO}_{3}$, solution fluxes in these plots (Van Miegroet et al., 1990a). On the other hand, our results suggested that, in the $\mathrm{N}$-rich soils, there was no such direct connection between $\mathrm{NO}_{3}-\mathrm{N}$ production and leaching. Net $\mathrm{N}$-mineralization and nitrification rates in the upper mineral soil of the conversion plots (AA and AF) were lower than in the undisturbed alder plot during summer, but such changes in net soil $\mathrm{N}$ mineralization were too small and temporary in nature to be able to account for a large part of the marked and prolonged reductions in $\mathrm{NO}_{3}^{-}$leaching measured in the conversion plots (Fig. 1; Van Miegroet et al., 1990a).

Harvesting increased the exposure of the soil to external climatic conditions, which was reflected in greater temperature extremes and generally lower moisture content of the upper soils in the alder conversion plots. The seasonal fluctuations in soil $\mathrm{N}$ dynamics typically observed in undisturbed alder stands (e.g., Van Miegroet et al., 1989; Binkley et al., 1991) was strongly attenuated in the alder conversion plots. Observed changes in net $\mathrm{N}$-mineralization and nitrification rates, however, were not directly correlated with changes in soil moisture or temperature regime in these conversion plots. Only in the uncut alder forest was there a significant (albeit small) positive correlation between nitrification and soil temperature.

Because living roots were excluded from the soil samples during the incubation assays, plant uptake was not a factor influencing $\mathrm{N}$-mineralization and nitrification patterns, although it may have played a role in regulating $\mathrm{NO}_{3}^{-}$leaching rates. Other processes that may have affected $\mathrm{NO}_{3}$ fluxes, but were not directly tested in this study, include (i) a significant reduction in leaf litter input and root detritus to the forest floor and mineral soil, (ii) the effect of litter quality and age on $\mathrm{N}$ immobilization, and (iii) the dynamics of the understory vegetation. The potential for fresh red alder leaf litter to serve as a readily mineralizable $\mathrm{N}$ source has indeed been indicated by a significant release of $\mathrm{N}$ during the initial stages of leaf litter decomposition (Edmonds, 1980), but less is known about the effect of later decomposition stages on $\mathrm{N}$ dynamics.

The establishment of red alder seedlings after the removal of either the Douglas fir or red alder forest cover did not appear to have affected $\mathrm{N}$-mineralization, nitrification, or $\mathrm{NO}_{3}^{-}$leaching rates in the upper mineral soil. Such lack of response was not entirely unexpected in the N-poor soil previously occupied by Douglas fir, because it may take many years of symbiotic $\mathrm{N}_{2}$ fixation by alder to build up the soil $\mathrm{N}$ content sufficiently to alleviate the competition for available $\mathrm{N}$ among microorganisms and stimulate nitrification. The soils previously under alder forest cover, however, were already enriched in terms of $\mathrm{N}$, and the apparent lack of $\mathrm{N}$-mineralization and nitrification response following harvesting and reestablishment of $\mathrm{N}_{2}$ fixing alder could not simply be explained in terms of soil $\mathrm{N}$ content. From these observations, we concluded that soil processes were still largely controlled by site characteristics associated with the previous forest cover, or by changes in these properties caused by harvesting, and not by forest conversion per se. Processes such as $\mathrm{N}$ input via leaf litterfall and forest floor decomposition or fine-root turnover may prove to play a critical role in soil $\mathbf{N}$ dynamics. It is also possible, although still highly speculative, that the decomposition of more recalcitrant litter material or changes associated with understory dynamics in the conversion areas caused changes in soil or solution chemistry (e.g., through release of organics, cf. Lewis, 1963; Rice and Pancholy, 1973, 1974) that suppressed microbial activity, or that changes in litter quality caused a change in the relative balance between $\mathrm{N}$ immobilization and mineralization. The factors responsible for the observed $\mathrm{NO}_{3}$ leaching patterns are not entirely clear and need to be investigated further.

\section{ACKNOWLEDGMENTS}

This is a contribution from the College of Forest Resources, University of Washington, and the Environmental Sciences Division, Oak Ridge National Laboratory. The research was funded by the Electric Power Research Institute under Contract RP-2621 with Martin Marietta Energy Systems, Inc., under Contract DE-AC05-840R21400 with the U.S. Department of Energy.

\section{REFERENCES}

Berg, B., and H. Staaf. 1981. Leaching, accumulation and release of nitrogen in decomposing litter. Ecol. Bull. (Stockholm) 33:163-178.

Bigger, C.M., and D.W. Cole. 1983. Effects of harvesting intensity on nutrient losses and future productivity in high and low productivity red alder and Douglas-fir stands. p. 167-178. In R. Ballard and S.P. Gessel (ed.) Proc. of the IUFRO Symposium on forest site and continuous productivity. U.S. For. Serv. PNW Gen. Tech. Rep. PNW-163. Pac. Northwest For. Range Exp. Stn. Portland, OR.

Binkley, D. 1981. Nodule biomass and acetylene reduction rates of red alder and Sitka alder on Vancouver Island, B.C. Can. J. For. Res. 11:281-286.

Binkley, D., J.P. Kimmins, and M.C. Feller. 1982. Water chemistry profiles in early- and mid-successional forests of coastal British Columbia. Can. J. For. Res. 12:240-248.

Binkley, D., P. Sollins, R. Bell, D. Sachs, and D. Myrold. 1992. Nitrogen biogeochemistry of adjacent conifer and alder/conifer ecosystems. Ecology (in press).

Bormann, B.T., and D.S. DeBell. 1981. Nitrogen content and other soil properties related to age of red alder stands. Soil Sci. Soc. Am. J. 45:428-432.

Bormann, F.H., G.E. Likens, T.G. Siccama, R.S. Pierce, and J.S. Eaton. 1974. The export of nutrients and recovery of stable conditions following deforestation at Hubbard Brook. Ecol. Monogr. 44:255-277.

Cole, D.W., J. Compton, H. Van Miegroet, and P. Homann. 1990. Changes in soil properties and site productivity caused by red alder. Water Air Soil Pollut. 54:231-246.

Cole, D.W., and S.P. Gessel. 1965. Movement of elements through a forest soil as influenced by tree removal and fertilization addition. p. 95-104 In C.T. Youngberg (ed.) Forest Soil Relationships in North America. Oregon State Univ. Press, Corvallis, OR.

Cole, D.W., and S.P. Gessel. 1968. Cedar River Watershed-A program for studying pathways, rates and processes of elemental cycling in a forest ecosystem. Univ. of Washington, Inst. of For. Prod., For. Resour. Monogr. 4. Univ. of Washington, Seattle.

Cole, D.W., S.P. Gessel, and J. Turner. 1978. Comparative mineral cycling in red alder and Douglas-fir. p. 327-336 In D.G. 
Briggs et al. (ed.) Utilization and management of alder. U.S. For. Serv. Gen. Tech. Rep. PNW-70. Pac. Northwest For. Range Exp. Stn., Portland, OR.

Cole, D.W., and M. Rapp. 1981. Elemental Cycling in forest Ecosystems. p. 341-409. In D.E. Reichle (ed.) Dynamic properties of forest ecosystems. Cambridge Univ. Press, Cambridge, England.

Davidson, E.A., J.M. Stark, and M.K. Firestone. 1990. Microbial production and consumption of nitrate in an annual grassland. Ecology 71:1968-1975.

DeBell, D.S., and M.A. Radwan. 1979. Growth and nitrogen relations of coppiced black cottonwood and red alder in pure and mixed plantings. Bot. Gaz. (Chicago) 140:5102-5107.

DeBell, D.S., M.A. Radwan, and J.M. Kraft. 1983. Influence of red alder on chemical properties of a clay loam soil in western Washington. U.S. For. Serv. Res. Pap. PNW-313. Pac. Northwest For. Range Exp. Stn., Portland, OR.

Edmonds, R.L. 1980. Litter decomposition and nutrient release in Douglas-fir, red alder, western hemlock, and pacific silver fir ecosystems in western Washington. Can J. For. Res. 10:327337.

Ellis, R.C. 1974. The seasonal pattern of nitrogen and carbon mineralization in forest and pasture soils in Southern Ontario. Can. J. Soil Sci. 54:15-28.

Eno, C. 1960 . Nitrate production in the field by incubating the soil in polyethylene bags. Soil Sci. Soc. Am. Proc. 24:277279.

Franklin, J.F., C.T. Dyrness, D.G. Moore, and R.F. Tarrant. 1968. Chemical soil properties under coastal Oregon stands of alder and conifers. p. 157-172 In J.M. Trappe et al. (ed.) Biology of alder. U.S. For. Serv. Pac. Northwest For. Range Exp. Stn., Portland, OR.

Haynes, R.J. 1986. Mineral nitrogen in the soil-plant system. Academic Press, Orlando, FL.

Heilman, P. 1974. Effect of urea fertilization on nitrification in forest soils of the Pacific Northwest. Soil Sci. Soc. Am. Proc. 38:664-667.

Johnson, D.W., and N.T. Edwards. 1979. Effect of stem girdling on biogeochemical cycles in deciduous forest of eastern Tennessee. II. Soil mineralization and nitrification rates. Oecologia 40:259-271.

Johnson, D.W., N.T. Edwards, and D.E. Todd. 1980. Nitrogen mineralization, immobilization, and nitrification following urea fertilization of a forest soil under field and laboratory conditions. Soil Sci. Soc. Am. J. 44:610-616.

Johnson, D.W., and S.E. Lindberg. 1992. Atmospheric deposition and nutrient cycling in forest ecosystems. Springer-Verlag, New York.

King, J.E. 1966. Site index curves for Douglas-fir in the Pacific Northwest. Weyerhaeuser For. Pap. no. 8. Weyerhaeuser, Centralia, WA.

Lewis, D.G. 1963. Partial inhibition of nitrate production by products of the mineralization of soil organic matter. J. Agric. Sci. 61:349-352.

Likens, G.E., F.H. Bormann, and N.M. Johnson. 1969. Nitrification-Importance of nutrient losses from a cutover forested ecosystem. Science (Washington, DC) 163:1205-1206.

Mann, L.K., Johnson, D.W., West, D.C., Cole, D.W., Hornbeck, J.W., Martin, C.W., Riekerk, H., Smith, C.T., Swank, W.T., Tritton, L.M., and Van Lear, D.H. 1988. Effects of whole-tree and stem-only clear-cutting on postharvest hydrologic losses, nutrient capital, and regrowth. For. Sci. 34:412428.

Melillo, J.M., J.D. Aber, and J.F. Muratore. 1982. Nitrogen and lignin control of hardwood leaf litter decomposition dynamics. Ecology 63:621-626.

Nadelhoffer, K.J., J.D. Aber, and J.M. Melillo. 1983. Leaf-litter production and soil organic dynamics along a nitrogen-availability gradient in southern Wisconsin. Can. J. For. Res. 13:1221.

Pang, P.C.K. 1982. Distribution of available nitrogen in undisturbed forest soil cores following fertilization with urea and ammonium nitrate. Soil Sci. Soc. Am. J. 46:632-637.
Pastor, J., and W.M. Post. 1986. Influence of climate, soil moisture, and succession on forest carbon and nitrogen cycles. Biogeochemistry 2:2-27.

Powers, R.F. 1990. Nitrogen mineralization along an altitudinal gradient: Interactions of soil temperature, moisture, and substrate quality. For. Ecol. Manage 30:19-29.

Rice, E.L., and S.K. Pancholy. 1973. Inhibition of nitrification by climax ecosystems. II. Additional evidence and possible role of tannins. Am. J. Bot. 60:691-702.

Rice, E.L., and S.K. Pancholy. 1974. Inhibition of nitrification by climax ecosystems. II. Inhibitors other than tannins. Am. J. Bot. 61:1095-1103.

Riha, S.J., G.S. Campbell, and J. Wolfe. 1986. A model of competition for ammonium among heterotrophs, nitrifiers, and roots. Soil Sci. Soc. Am. J. 50:1463-1466.

Rosswall, T. 1976. The internal nitrogen cycle between microorganisms, vegetation, and soil. Ecol. Bull. (Stockholm) 22:157167.

SAS Institute. 1985. SAS user's guide. Statistics. Version 5 ed. SAS Inst., Cary, NC.

Soil Conservation Service. 1986. Revision of Soil Survey of King County, WA. USDA Soil Conservation Service, Pullman, WA.

Swank, W.T. 1986. Biological control of solute losses from forest ecosystems p. 85-139 In S.T. Trudgill (ed.) Solute processes. John Wiley \& Sons, Ltd., Chichester, England.

Turner, J., D.W. Cole, and S.P. Gessel. 1976. Mineral nutrient accumulation and cycling in a stand of red alder (Alnus rubra). J. Ecol. 64:965-974.

Van Cleve, K., L.A. Viereck, and R.L. Schlentner. 1971. Accumulation of nitrogen in alder ecosystems near Fairbanks, Alaska. Arct. Alp. Res. 3:101-114.

Van Miegroet, H., and D.W. Cole. 1984. The impact of nitrification on soil acidification and cation leaching in a red alder forest. J. Environ. Qual. 13:585-590.

Van Miegroet, H., and D.W. Cole. 1989. Influence of N-fixing alder on acidification and cation leaching in a forest soil. p. 113-124 In D.W. Cole and S.P. Gessel (ed.) Forest site evaluation and long-term productivity. Univ. of Washington Press, Seattle.

Van Miegroet, H., D.W. Cole, D. Binkley, and P. Sollins. 1989. The effect of nitrogen accumulation and nitrification on soi chemical properties in alder forests. p. 515-528 in R.K. Olson and A.S. LeFohn (ed.) Effects of air pollution on western Forests. Air and Waste Manage. Assoc., Pittsburgh, PA.

Van Miegroet, H. D.W. Cole, and P.S. Homann. 1990a. The effect of alder forest cover and alder forest conversion on site fertility and productivity. p. 333-354 In S.P. Gessel et al., (ed.) Sustained productivity of forest soils. Proc. of the 7th North American Forest Soils Conf. Univ. of British Columbia, Faculty of Foresty Publ., Vancouver, BC., Canada.

Van Miegroet, H., D.W. Johnson, and D.W. Cole. 1990b. Soil nitrification as affected by $\mathbf{N}$ fertility and changes in forest floor $\mathrm{C} / \mathrm{N}$ ratio in four forest soils. Can. J. For. Res. 20:1012-1019.

Vitousek, P., J.R. Gosz, C.C. Grier, J.M. Melillo, and W.A. Reiners. 1982. A comparative analysis of potential nitrification and nitrate mobility in forest ecosystems. Ecol. Monogr. 52:155177.

Vitousek, P. J.R. Gosz, C.C. Grier, J.M. Melillo, W.A. Reiners, and R.L. Todd. 1979. Nitrate losses from disturbed ecosystems. Science (Washington, DC) 204:469-474.

Waide, J.B., W.H. Caskey, R.L. Todd, and L.R. Boring. 1987. Changes in soil nitrogen pools and transformations following clearcutting. p. 221-243 In W.T. Swank and D.A. Crossley, Jr. (ed.) Forest hydrology and ecology at Coweeta. SpringerVerlag, New York.

Zar, J.H. 1974. Biostatistical Analysis. Prentice-Hall, Englewood Cliffs, NJ.

Zavitkovski, J., and M. Newton. 1968. Effect of organic matter and combined nitrogen on nodulation and nitrogen fixation in red alder. p. 209-221 In J.M. Trappe et al. (ed.) Biology of alder. U.S. For. Serv. Pac. Northwest For. Range Exp. Stn., Portland, OR. 